\title{
Implementation of Lean Manufacturing System for Successful Production System in Manufacturing Industries
}

\author{
Mohd Shoeb \\ Department of Mechanical Engineering, Jamia Millia Islamia New Delhi, (India)
}

\begin{abstract}
In manufacturing industries lean manufacturing is a broadly accepted philosophy. There are more requirements of research and studies. To investigate the needs, techniques, benefits of lean manufacturing and approaches for implementation Lean manufacturing is a leading manufacturing paradigm has applied in many economy sectors, where we have to reduce manufacturing cost, improving product quality, reducing cost of poor quality, and quick to respond and "first to market to customer needs are critical to competitiveness and success. Lean methods and principle focus on the continuous improvement and engages employees reducing the intensity of materials, time, and capital necessary for meeting a customer's needs. Successful implementation of lean manufacturing is very important to increase quality and waste reduction. By implementation of lean manufacturing there are various benefits such as waste elimination, reduction in reworking, financial benefits, lead time reduction and lower inventory levels.
\end{abstract}

Keywords: Product quality: Lean Production: Cost of poor quality: Continual improvement: Waste elimination.

\section{INTRODUCTION}

Lean manufacturing is most powerful manufacturing systems in the world. Numerous plants around the world have attempted to implement or adopt it to enhance their efficiency [1]. It can increase the environmental and economic performance inside a supply chain domain. It can help to take into a account for environmental factors in the whole process through their collaboration of upstream and downstream enterprises, including purchase of raw materials, manufacturing of intermediate products or finished products, and delivery of finished products to end users through sales network. It appears an environmental innovation in current scenario which integrates environmental concerns. There is the reduction of unwanted material and other resources as it indirectly reduces the amount of waste at manufacturing such as concept of Green supply chain management $[11,13,22]$

The respondent firms are classified as intransition towards lean manufacturing practice. These in-transition firms have moderate mean values for each of the five lean manufacturing practice categories. It is also found that these firms spend more resources and attention in internal areas such as firms' operation and management, compared to external relationships with customers and suppliers. These firms believe that the factors that drive the implementation of lean manufacturing are the desire to focus on customers and to achieve the organization's continuous improvement [4].
The manufacturing industries are identified during the production of product there are leaner. The major green wastes from their disposal methods have high influence on environment. These wastes have to be reduced or eliminated by practicing a suitable Green supply chain and lean concept. In present most of the companies doesn't practice any supply chain in their organization. The implement of green supply chain and lean manufacturing could decrease the wastes of the industries and environmental pressures to some extent [16].

Lean Manufacturing is a valuable approach to eliminating waste and identifying through continuous improvement. In India manufacturing industry must look to leverage its advantages, good conditions in terms of raw materials, its large domestic market and skilled labour and the quality focus. "Lean manufacturing" is a leading manufacturing paradigm being applied in many sectors of the economy, where product quality has been improved, reduce inventory level, reducing production costs by reducing cost of poor quality, decreased material [2]. Lean manufacturing was developed for maximizing the resource utilization through minimization of waste. Later on lean was formulated in response to the competitive and fluctuating business environment. Due to fast changing business environment the organizations are forced to face complexities and challenges. Any organization whether service or manufacturing or oriented to survive may ultimately depend on its ability to systematically and continuously respond to these changes for enhancing the product value. 
Therefore value adding process is necessary to achieve this perfection; hence implementing a lean manufacturing system is becoming a core competency for any type of organizations to sustain [3].

The practices and principles of Lean manufacturing are widely used by industries to eliminate waste and make more efficient process. Lean has been recognized as one of the key approaches in enhancing the productivity and hence the competitiveness of an organization is increased [5].

\section{METHODS AND PRINCIPLES OF LEAN MANUFACTURING}

Eight core lean methods are used in Lean

Manufacturing described below:

$>$ Just-in-time Production

$>$ Kaizen

$>5 \mathrm{~S}$

$>$ Cellular Manufacturing

$>$ Total Productive Maintenance (TPM)

$>$ Six Sigma

$>$ One-piece Flow Production Systems

$>$ Pre-Production Planning

$>$ Kanban

\section{Principles}

Following are the main basic principles of the lean manufacturing:-

$>$ Identify Value

$>$ Map the Value Stream
$>$ Create the Flow

$>$ Establish Pull

$>$ Seek the Perfection

Today lean manufacturing concept has apply in many industries including service provider, healthcare and even military. The organizations variety that are practicing lean concepts in them goes to show the universal applicability of lean thinking or lean concepts. Lean technologies may be unique to the implementation but the lean thinking is universal. Lean can be implemented in engineering, production, sales, planning, / maintenance, marketing, store, Research and Development etc [29].

\section{SEVEN MAIN WASTAGES IN INDUSTRY}

There are seven main wastages in the manufacturing industries [31]. By removing these wastages manufacturing industries increase profit and smooth production which are shown in fig 1 and discussed below:

Overproduction: Production of products which are above the requirement of customer at that point.

Rejection: The product which is not as per the requirement is considered as a scrap and waste.

Transportation: During production when there is unnecessary movement of the parts which does not add any value to the product and considered as a waste.

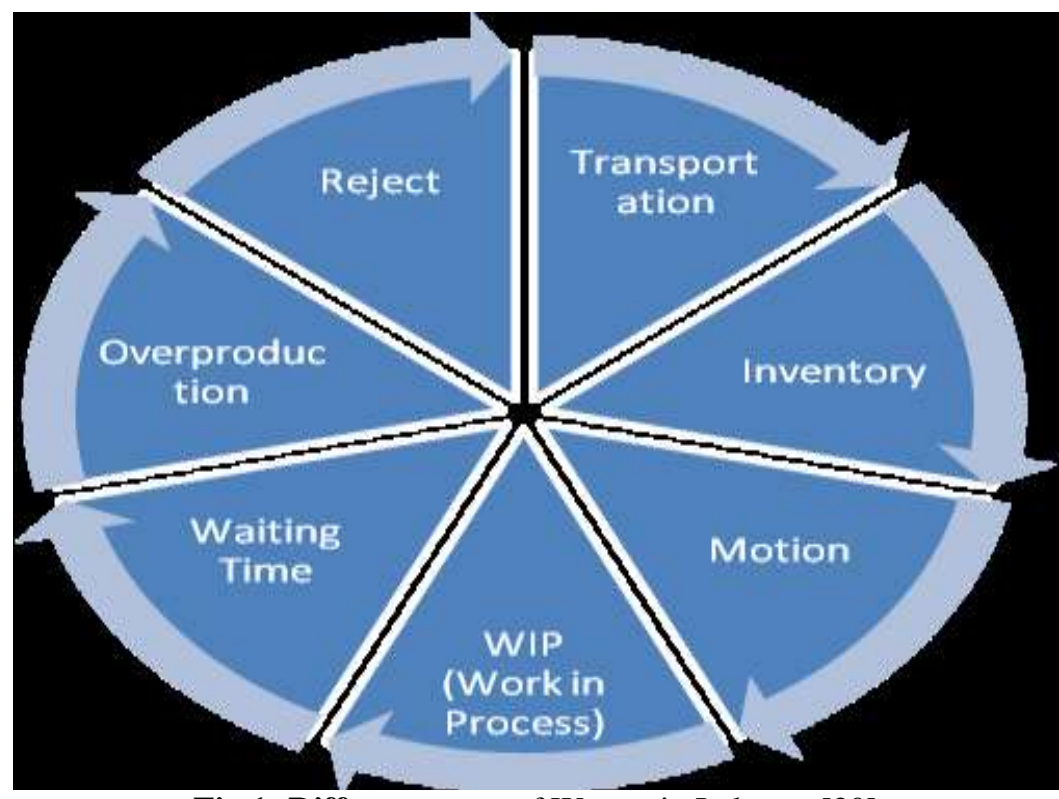

Fig 1: Different types of Wastes in Industry [30]

Inventory: Stocks of products waiting to be shipped or parts waiting to be finished. Inventory of any kind is carried as a waste in the industries.
Motion: On the shop Unnecessary movement of the workers floor is considered as a waste. 
Work in Process (WIP): Over production and waiting time also results of waste. It is also a type of waste.

Waiting Time: Unnecessary waiting by the worker or the product is waiting to be processed on the next work station. It is also considered as a waste.

\section{SUCCESSFUL IMPLEMENTATION OF LEAN ELEMENTS}

The perfect manufacturing system can be achieved through successful implementation of lean elements. For successful implementation of lean, practically need incorporation of all lean elements and sequencing of implementation task [3]. Various successful implementations of lean elements are as:

$>$ Scheduling

$>$ Takt time

$>$ Value stream mapping (VSM)

$>$ Bottleneck process

$>$ Cellular manufacturing $(\mathrm{CM})$

$>$ Group Technology

$>$ Line balancing

$>$ U-line manufacturing system

$>$ Flow Manufacturing

> Small Lot size/Small Batch

> Quick Changeover/Single Minute Exchange of Die

$>$ Inventory

$>$ Production Levelling/ Heijunka

$>$ Pull System with One-Piece Flow

$>$ Kanban

$>$ Continuous Improvement $(\mathrm{CI}) /$ Kaizen

$>$ Quality at source

$>$ Standardized Work

\section{THE BENEFITS OF LEAN}

Whether we are looking to cut costs, gain a competitive advantage, or remain viable in the face of competition that has gone lean, there are many reasons to adopt lean manufacturing techniques in your company. Lean benefits include reduced work-in-process, increased capacity, increased inventory turns, cycle-time reduction, and improved customer satisfaction. According to a recent survey [10] of 40 companies that had adopted lean manufacturing, typical improvements [8].

\section{Operational Improvements}

$>$ A $90 \%$ reduction in lead time (cycle time)

$>$ An $80 \%$ reduction in work-in-process inventory

$>$ A 50\% increase in productivity

$>$ A 75\% reduction in space utilization

$>$ An $80 \%$ improvement in quality

\section{Administrative Improvements}

$>$ Reduction in order processing errors
$>$ Reduction of paperwork in office areas

$>$ Streamlining of customer service functions so that customers are no longer placed on hold

$>$ Reduced staffing demands, allowing the same number of office staff to handle larger numbers of orders

$>$ Reduction in turnover and the resulting costs of attrition

$>$ Documentation and streamlining of processing steps, enabling noncritical functions to be outsourced and allowing the company to focus its efforts on customer's needs

$>$ Implementation of job standards and preemployment profiling, ensuring the hiring of only above-average performers (imagine the benefit to the organization if everyone performs as well as the top 20\%)

\section{LEAN MANUFACTURING SYSTEM DESIGN AND IMPLEMENTATION ISSUES}

Lean Manufacturing is delivering sustainable competitive advantage to organizations as a change and improvement strategy it has not been successfully implemented in Indian industries at large. The philosophy of lean is not new to Indian Industries as but they fail gain sustainable development through proper implementation of Lean manufacturing system. The related issues discussed in detail to have a clear cut idea about the tools and techniques necessarily to implement Lean manufacturing system. The management should be committed to LMS and the roles and responsibilities of employees should be well defined [28].

\section{Implementation Issues}

There are issues which are necessary for the implementation lean manufacturing system [28].The overview of these issues bring significant business improvements while implementing lean manufacturing system which are as under:

$>$ Lead time reduction

$>$ Worker's (Employee) participation (Total Employee Involvement - TEI)

$>$ Inventory reduction

$>$ Quality Improvement (TQM)

$>$ Customer satisfaction

$>$ Maintenance (TPM) - Less breakdown maintenance

$>$ Vendor development and relationship

$>$ New product (faster introduction)

$>$ Improved housekeeping \& Material Handling

$>$ Throughput Time (Better delivery performance) 


\section{EIGHT TYPE OF MANUFACTURING WASTE TARGETED BY LEAN METHODS}

Lean manufacturing methods typically target eight types of waste [9]. These waste types are discussed in Table 1. It is interesting to note that the "wastes" typically targeted by environmental management agencies, such as non-product output and raw material wastes, are not explicitly included in the list of manufacturing wastes that lean practitioners routinely target.

Table 1. Eight Types of manufacturing waste

\begin{tabular}{|c|c|c|c|}
\hline S.No & Waste type & Description & References \\
\hline 1 & Defects & $\begin{array}{l}\text { Production of off-specification products, components } \\
\text { or services that result in scrap, rework, replacement } \\
\text { production, inspection, and/or defective materials }\end{array}$ & [20] \\
\hline 2 & Over production & Manufacturing items for which there are no orders & [24] \\
\hline 3 & $\begin{array}{l}\text { Unnecessary } \\
\text { processing }\end{array}$ & $\begin{array}{l}\text { Process steps that are not required to produce the } \\
\text { product }\end{array}$ & [21] \\
\hline 4 & Waiting & $\begin{array}{l}\text { Delays associated with stock-outs, lot processing } \\
\text { delays, equipment downtime, capacity bottlenecks }\end{array}$ & [20] \\
\hline 5 & Inventory & Excess raw material, WIP, or finished goods & [25] \\
\hline 6 & Complexity & $\begin{array}{l}\text { More parts, process steps, or time than necessary to } \\
\text { meet customer needs }\end{array}$ & [26] \\
\hline 7 & $\begin{array}{l}\text { Unused } \\
\text { Employee }\end{array}$ & $\begin{array}{l}\text { Creativity Failure to tap employees for process } \\
\text { improvement suggestions }\end{array}$ & [23] \\
\hline 8 & Movement & $\begin{array}{l}\text { Human motions that are unnecessary or straining, } \\
\text { and work-in-process (WIP) trans- porting long } \\
\text { distances }\end{array}$ & [27] \\
\hline
\end{tabular}

\section{LEAN MANUFACTURING TOOLS} AND TECHNIQUES

There are various tools and techniques used to enhance lean manufacturing system which are as:

$>$ Cellular manufacturing

$>$ Muda, Muri \& Mura

$>$ Pull production

$>$ Just-In-Time

$>$ Standardization of work

$>$ Kaizen (Continuous improvement)

$>$ Production smoothing

> Total Productive Maintenance

$>$ Pokayoke
$>$ Other waste reduction techniques (such as setup reduction, zero defects, line balancing etc.)

$>$ PDCA Cycle etc.

\section{SUCCESSFUL IMPLEMENTATION OF LEAN MANUFACTURING SYSTEM IN MANUFACTURING INDUSTRIES}

According to Black and Hunter [10] the steps are numbered and the order of implementation should exactly follow the step order. The ten steps and a brief description are given in Table 2 :

Table 2: Successful implementation of LMS in Manufacturing Industries

\begin{tabular}{|l|l|l|l|}
\hline S.No & Steps & Description & References \\
\hline 1 & $\begin{array}{l}\text { Reengineering the } \\
\text { Manufacturing } \\
\text { System }\end{array}$ & $\begin{array}{l}\text { Restructure/reorganize fabrication and assembly [19] } \\
\text { systems into cells that produce families of } \\
\text { parts/products. The cells should have one-piece parts } \\
\text { movement within cells and small-lot movement } \\
\text { between cells, achieved by creating a linked-cell } \\
\text { system. }\end{array}$ & $\begin{array}{l}\text { Setup time for a cell should be less than manual time, [6] } \\
\text { or the time a worker needs to load, unload, inspect, } \\
\text { deburr etc. }\end{array}$ \\
\hline 2 & $\begin{array}{l}\text { Setup Reduction and } \\
\text { Elimination }\end{array}$ & $\begin{array}{l}\text { Integrate Quality } \\
\text { Manufacturing } \\
\text { The operation should be "Make-one, check-one, and [18] } \\
\text { move-on-one" type; and the quality of products output } \\
\text { from the system should be 100\%. }\end{array}$ & \\
\hline
\end{tabular}




\begin{tabular}{|c|c|c|c|}
\hline 4 & $\begin{array}{l}\text { Integrate Preventive } \\
\text { Maintenance into } \\
\text { Manufacturing }\end{array}$ & $\begin{array}{l}\text { There should be no equipment failure and the workers } \\
\text { should be trained to perform routine low level process } \\
\text { maintenance. }\end{array}$ & [17] \\
\hline 5 & $\begin{array}{lr}\text { Level, } & \text { Balance, } \\
\text { Sequence } & \text { and } \\
\text { Synchronize } & \end{array}$ & $\begin{array}{l}\text { Fluctuations in final assembly should be eliminated, } \\
\text { output from cells should be equal to the necessary } \\
\text { demand for parts downstream and the cycle time } \\
\text { should be equal to takt (available production time } \\
\text { divided by customer demand) time for final assembly. }\end{array}$ & [15] \\
\hline 6 & $\begin{array}{l}\text { Integrate Production } \\
\text { Control into } \\
\text { Manufacturing }\end{array}$ & $\begin{array}{l}\text { Cells respond to demand by delivering parts and } \\
\text { products only as they are needed, or just in time. }\end{array}$ & [12] \\
\hline 7 & $\begin{array}{l}\text { Reduce Work-In- } \\
\text { Process (WIP) }\end{array}$ & $\begin{array}{l}\text { Minimize the necessary WIP between cells, and parts } \\
\text { are handled one at a time within cells. }\end{array}$ & [14] \\
\hline 8 & Integrate Suppliers & $\begin{array}{l}\text { Reduce the number of suppliers and cultivate a single } \\
\text { source for each purchased component or subassembly. }\end{array}$ & [7] \\
\hline 9 & Automation & $\begin{array}{l}\text { Inspection should become part of the production } \\
\text { process ( } 100 \% \text { inspection) and there should be no } \\
\text { overproduction. }\end{array}$ & [24] \\
\hline 10 & $\begin{array}{l}\text { Computer-Integrated } \\
\text { Manufacturing }\end{array}$ & $\begin{array}{l}\text { Production system to be as free of waste as the } \\
\text { manufacturing system }\end{array}$ & [18] \\
\hline
\end{tabular}

\section{CONCLUSION}

Lean Manufacturing is a collection of techniques and philosophies that reduce waste and add value of the product. It is becoming more accepted and implemented in the manufacturing industry and essential to remain competitive in the long term. Most of the industries adopting lean manufacturing practices but its implementation is not in appropriate way. Some successful implementation is more necessary for effective production system; the focused should be on continuous improvement, has to focusing on systems approach, automation and upgradation of technology, implementation of new and emerging techniques which reduced costs, reduced lead time, and improved quality provide opportunities for new marketing campaigns. Lean is applicable for all the type of the organization irrespective of their size, lot of work has been carried out in manufacturing sector that to in different functional areas, the level of implementation varies across the sectors and their size. The Reduction of waste, Productivity improvement, Inventory reductions are commonly cited benefits across the lean implemented firms. Proper successful implementation of lean manufacturing is very essential part of manufacturing to enhance the quality and waste reduction.

\section{REFERENCES}

[1]. Wong, Y. C., Wang, K., (2011) “Approaches and practices of lean manufacturing: The case of electrical and electronics companies", African Journal of Business management. Volume No. 5 Issue No. 6, pp. 2164-2174.

[2]. Shoeb ,M., Javaid, M.,(2015)“Some Studies on Lean Manufacturing In Indian
Manufacturing Industries" International Journal of Advanced Technology in Engineering and Science. Volume No.03, Issue No. 06. pp 123-127

[3]. Sundara, R, Balajib, A.N., Kumar, R.M.S., (2014) "A Review on Lean Manufacturing Implementation Techniques" 12th GLOBAL CONGRESS ON MANUFACTURING AND MANAGEMENT, GCMM 2014. Procedia Engineering 97. Pp. 1875 - 1885

[4]. Nordin, N., Deros B. M., Wahab, D. A.,(2010) "A Survey on Lean Manufacturing Implementation in Malaysian Automotive Industry" International Journal of Innovation, Management and Technology, Vol. 1, No. 4. pp 374-380

[5]. Chaple, A. P., Narkhede, B. E., Akarte, M. M.,(2014)"Status of implementation of Lean manufacturing principles in the context of Indian industry: A Literature Review" 5th International \& 26th All India Manufacturing Technology, Design and Research Conference (AIMTDR 2014) December 12th-14th, 2014, IIT Guwahati, Assam, India. pp 567(1 -6)

[6]. Benjamin, S. J., Murugaiah, U. K., Marathamuthu, M.S., (2013) "The use of SMED to eliminate small stops in a manufacturing firm", Journal of Manufacturing Technology Management, Vol. 24 Issue: 5, pp.792-807,

[7]. McCullen, P., Towill, D., (2001) "Achieving lean supply through agile manufacturing",Integrated Manufacturing Systems, Vol. 12 Issue: 7, pp.524-533,

[8]. Kilpatrick, J., (2003) Lean Principles, Utah Manufacturing Extension Partnership. 
[9]. Productivity Development Team,(2000) “ Just-in-Time for Operators", Portland, Oregon: Productivity Press, 3.

[10]. Black J T and Hunter S L, 2003, "Lean Manufacturing System and Cell Design", SME.

[11]. Shoeb, M., Javaid, M., Kumar, M., (2014)“Recycling system Benefits for Green Supply Chain Management" International Journal of Advance Research In Science And Engineering Vol. No.3, Issue No.5. pp 15-20

[12]. Hedelind, M., Jackson, M., (2011) "How to improve the use of industrial robots in lean manufacturing systems", Journal of Manufacturing Technology Management, Vol. 22 Issue: 7, pp.891-905,

[13]. Javaid, M., Shoeb M.,(2016) "Impact of Green Supply Chain Management on the overall Performance of Industries" IJATES, vol 4(6). pp 381-385

[14]. Panwar, A., Jain, R., Rathore, A.P.S., (2015) "Lean implementation in Indian process industries - some empirical evidence", Journal of Manufacturing Technology Management, Vol. 26 Issue: 1, pp.131-160,

[15]. Bhasin, S., Burcher, P., (2006) "Lean viewed as a philosophy", Journal of Manufacturing Technology Management, Vol. 17 Issue: 1, pp.56-72,

[16]. Shoeb, M., Javaid, M., (2016) "Lean Manufacturing benificial for Green Supply Chain Management to reduce Global Warming” vol 4(6) 2016. pp 386-390.

[17]. Ahuja, I.P.S., Khamba, J.S., (2008) "Justification of total productive maintenance initiatives in Indian manufacturing industry for achieving core competitiveness", Journal of Manufacturing Technology Management, Vol. 19 Issue: 5, pp.645-669,

[18]. Vinodh, S., Shivraman, K.R., Viswesh, S., (2011) "AHP based lean concept selection in a manufacturing organization", Journal of Manufacturing Technology Management, Vol. 23 Issue: 1, pp.124-136,

[19]. Caputo, A. C., Pelagagge, P.M., (2003) "Manufacturing reengineering in a tubular radiator production plant", Integrated Manufacturing Systems, Vol. 14 Issue: 2, pp.95-102,

[20]. Wickramasinghe, G.L.D., Wickramasinghe, V., (2017) "Implementation of lean production practices and manufacturing performance: The role of lean duration", Journal of Manufacturing Technology Management, Vol. 28 Issue: 4, pp.531-550,

[21]. Ghosh, M., (2012) "Lean manufacturing performance in Indian manufacturing
plants",Journal of Manufacturing Technology Management, Vol. 24 Issue: 1, pp.113-122,

[22]. Javaid, M., Shoeb, M., (2015) "Benefits on Implementation of Green Supply Chain Management in Manufacturing Industries" International Journal of Advanced Technology in Engineering and Science. Volume No.03, Issue No. 06. Pp 128-132

[23]. Chowdary, B. V., George, D., (2011) "Improvement of manufacturing operations at a pharmaceutical company: A lean manufacturing approach", Journal of Manufacturing Technology Management, Vol. 23 Issue: 1, pp.56-75,

[24]. Pham, D.T., Pham, P.T.N., Thomas, A., (2008) "Integrated production machines and systems - beyond lean manufacturing", Journal of Manufacturing Technology Management, Vol. 19 Issue: 6, pp.695-711,

[25]. Taj, S., (2008) "Lean manufacturing performance in China: assessment of 65 manufacturing plants", Journal of Manufacturing Technology Management, Vol. 19 Issue: 2, pp.217-234,

[26]. Narayanamurthy, G., Gurumurthy, A.,(2016) "Systemic leanness: An index for facilitating continuous improvement of lean implementation", Journal of Manufacturing Technology Management, Vol. 27 Issue: 8, pp.1014-1053,

[27]. Anand, G., Kodali, R., (2008) "Selection of lean manufacturing systems using the PROMETHEE", Journal of Modelling in Management, Vol. 3 Issue: 1, pp.40-70,

[28]. Upadhye,N., Deshmukh, S. G., Garg, S.,(2010) "Lean Manufacturing for Sustainable Development" Global Business and Management Research: An International Journal Vol. 2, No. 1. pp. 125-137

[29]. Mehta, R.K., Mehta,D., Mehta, N.K.,(2012) "Lean Manufacturing Practices: Problems and Prospects" Annals of Faculty Engineering Hunedoara - International Journal Of Engineering Tome X(2012) pp 119-124.

[30]. Abhishek, D., Sanjay, P., Anupam , D., (2011) "Lean Manufacturing to lean enterprises" proceedings of the International Conference on Industrial Engineering held at SVNIT, Surat, November 17-19, 2011, pp431-435.

[31]. Kumar, A., (2014) “A Qualitative Study on the Barriers of Lean Manufacturing Implementation: An Indian Context (Delhi Ncr Region)" The International Journal Of Engineering And Science (IJES). Vol 3(4). Pp 21-28 